\section{REIMAGINING EDEN: HOMOEROTIC RELATIONSHIPS IN EMILY DICKINSON'S POETRY}

\section{Chutima Pragatwutisarn ${ }^{1}$}

\begin{abstract}
The homoerotic relationship is one of the major themes in Emily Dickinson's poetry. Critics have constantly looked for evidence of homoeroticism in the poet's life and work. In this essay, I argue that feminist psychoanalysis, particularly theories of the mother-daughter relationship, is useful to an understanding of the homoerotic in Dickinson's poems. In her rereading of psychoanalytical theories, Nancy Chodorow emphasizes the symbiotic relationship between the mother and daughter and the daughter's marginal position within the symbolic order. Chodorow's theoretical framework has been applied to the analysis of female writers, including Dickinson, who write from the position of the daughter. In "The Parable of the Cave," Sandra Gilbert and Susan Gubar narrate the myth told by Mary Shelley about her search for a literary foremother, the Sibyl, from whom Shelley derived her creative power. Dickinson's poetry, similar to the parable told by Shelley, depicts a speaker who is alienated from the patriarchal world of law and order and is looking for the lost mother world usually personified by nature. For Dickinson, the recovery of Eden or the female utopia is significant
\end{abstract}

\footnotetext{
${ }^{1}$ Lecturer, Department of Comparative Literature, Faculty of Arts, Chulalongkorn University
}

not only for her female self-affirmation but also in her assertion as a female author.

Within the body growing as a graft, indomitable,

There is an other.-Julia Kristeva, Desire in Language

Ourself behind ourself, concealed-

Should startle most.-Emily Dickinson, poem \#670

\section{Introduction}

Jacques Lacan's ${ }^{2}$ rewriting of the Freudian family romance locates the subject within a language fabricated by men. In this patriarchal discourse or symbolic order, the story of the mother-daughter relationship is forbidden and lost. The world is compensated for by his possession of paternal power signified by the phallus. The feminist revision of Lacan's androcentric myth, seen in the work of such critics as Nancy Chodorow, Sandra Gilbert and Susan Gubar, focuses on the rediscovery of the mother-daughter plot that has been suppressed by patriarchal culture. As the epigraphs by Kristeva and Dickinson suggest, the female body is not simply a locus of patriarchal control of power but also a site of subversion as the daughter, who is of the same sex as the mother, is able to retain her pre-oedipal and thus homosexual relationship with the mother. Dickinson's poetry can be understood

\footnotetext{
${ }^{2}$ My discussion of Jacques Lacan is derived from Kaja Silverman, The Subject of Semiotics (New York: Oxford University Press, 1983), Tamsin E. Lorraine, Gender, Identity, and the Production of Meaning (Boulder: Westview Press, 1990), and Elizabeth Wright, Psychoanalytic Criticism: Theory in Practice (London: Methuen, 1984).
} 
within the context of the gynocritic myth offered by these feminist critics. A close examination of Dickinson's poems reveals a subtext - her attempt to reconstruct a lost paradise, the pre-symbolic realm of the mother. Many of Dickinson's poems dramatize the female protagonist's exile from the Kingdom of the Father, the patriarchal culture where she is regarded as the Other. Seeing herself as powerless and her desire unfulfilled, the protagonist is searching for the mother land of milk and honey. This female utopia is envisioned by Dickinson in several poems as an Eden, a secret female enclave where the protagonist experiences a joyful bliss derived from a homoerotic relationship with the mother's body in nature.

\section{I}

Lacan's rereading of Freud's family romance focuses on the role of language in the construction of subjectivity ${ }^{3}$. The Lacanian subject is seen as an effect of linguistic construction, the subject of semiotics whose basic nature is defined as 'lack'. This Lacanian scheme of the development of subjectivity revolves around two important stages: the presymbolic or pre-oedipal and the symbolic. The pre-symbolic is the realm of the Mother characterized by the mother-child dyad. From its direct contact with the mother's body, the child experiences bliss or jouissance. At this stage, the child does not recognize any lack and perceives itself as whole and unitary. In the mother-child dyadic relationship, the mother functions as the other and her gaze, like a mirror,

\footnotetext{
${ }^{3}$ In the Lacanian scheme, the terms " $[\mathrm{m}]$ other and father signify cultural positions and hence have no necessary correlation to biological realities." See Silverman (1983: 182).
}

reflects back the child image as a whole. It must be emphasized, however, that the child's discovery of selfhood as completeness and wholeness through its identification with the mother is considered by Lacan to be a fantasy or illusion. $^{4}$

The mother-child dyad breaks up when the child enters the realm of signification or symbolic order governed by what Lacan calls the Name of the Father or le Nom du Pere. In Psychoanalytic Criticism, Elizabeth Wright argues that the French word "Nom" (name) is a pun on "Non" (no), indicating the suppression of the child's desire for the mother. In the symbolic realm, the male child turns away from the mother to identify with his father who possesses the phallus, the central symbol of power. The lack of a phallus in the female child, on the other hand, allows her only indirect connection with her father through having her own child who will provide a phallus for her. The phallus thus comes to determine the subject's social identity. The child's learning of gender difference is accompanied by its acquisition of language - the Father's words which compensate for the absence of the mother. However, desire originated by lack will never be satisfied by language which simply launches an endless chain of signification from one signifier to the next. While there is a 'Paradise Regained' for the male subject, the fusion with the mother, once lost to the female child, is

\footnotetext{
${ }^{4}$ Lacan calls this stage of development the mirror stage in which "the $I$ is precipitated in a primordial form, before it is objectified in the dialectic of identification with the other, and before language restores to it, in the universal, its function as subject." The I, existing in this form, is according to Lacan "the Ideal-I." See Lacan (1977: 2).
} 
lost forever in Lacan's scheme. The loss of the mother to the daughter, says Lorraine (1990: 66), is "complete since she will never have the phallus, never have the mother back."

Lacan's theory of subjectivity reveals one important fact: psychoanalysis can be seen as a discourse of power. Discourse, argues Wright (1984: 159), "implies rules which define what is to be considered relevant and unmentionable." Similarly, the discourse of psychoanalysis operates by submission and withdrawal of certain facts in order to suture any seams, smooth over contradictions and finally provide presentable conditions of existence. Hence, Homans (1986: 6) notes, "In the Lacanian myth, language and gender are connected in such a way as to privilege implicitly the masculine and the figurative." The order of the symbolic is the order of language, of culture, of paternal laws that privilege the male subject who possesses the phallus. ${ }^{5}$ Within the order the bond between mother and daughter is not only forgotten and lost but also replaced by that between father and son. The Father's law substitutes the word for the mother's body and introduces desire as a result of the lack or absence of the mother's body. The absence of the mother from the symbolic order makes it possible to uphold patriarchal culture. Therefore, in the Lacanian model, the mother must be 'killed' and her story must be suppressed in order to launch an infinite chain of signification.

\footnotetext{
${ }^{5}$ In This Sex Which Is Not One, Luce Irigaray unmasked the "phallocentrism" embedded in the Western system of representation, showing how masculine logic has been the point of reference for the discourse of language. See Irigaray's critique of Freud's psychoanalytic discourse (1985: 68-85).
}

Since Lacan's discourse of family romance has had a profoundly damaging effect on women, the feminist revision of this androcentric myth by such critics as Nancy Chodorow, Sandra Gilbert and Susan Gubar is extremely welcome and indispensable. In her influential essay, "When We Dead Awaken: Writing as Revision," Rich (1979: 35) says, "Revision - the act of looking back, of seeing with fresh eyes, of entering an old text from a new critical direction-is for women more than a chapter in cultural history: it is an act of survival". As we have seen in the Lacanian scheme, the mother is imprisoned, silenced and buried in the masculine discourse. Revision, Rich (1979: 35) further argues, "is more than a search for identity: it is part of our refusal of the self-destructiveness of maledominate society". Therefore, it is not surprising that the feminist project of revision, carried out by critics such as Chodorow, Gilbert and Gubar, reveals an attempt to revive the primacy of the preoedipal, the realm of the Mother, and the bond between mother and daughter. Describing this version of the feminist family romance, Hirsch (1989: 138) says it is "the romance of the daughter, entangled with the mother through identification and struggle against it, increasingly distant from the father, brother, and male lover, unproblematic only in the connection to her sister or female lover." This separation from men and the creation of a separate all-female realm on the borders of patriarchal culture is fundamental to the feminist family romance.

Chodorow's The Reproductions of Mothering offers an incisive critique and revision of gender development. According to Chodorow, the establishment of gender identity occurs well before the oedipal complex mainly through the 
child's relationship with the mother, its primary caretaker. The mother is of the same gender as her daughter and of a different gender from her son; thus she treats them differently. The daughter is regarded as an extension of the mother's self while the son is not. This symbiotic relationship with the mother which is prolonged in the female child also influences the child's formation of ego boundaries. If "the basic feminine sense of the self," says Chodorow (1978: 95), "is connected to the world, the basic masculine sense of the self is separate" (1978: 95). While the son must establish his gender identity in opposition to the mother, the daughter's lengthy identification with her mother results in her fluid ego boundaries. More important is Chodorow's notion that the boy's oedipal complex is more decisively resolved than the girl's. In her discussion of Chodorow's book, Homans (1986: 1112) notes that castration never comes to the daughter as a threat. The girl, who has the same sex as her mother, is not considered by her father as a rival and is not far enough from her mother to have devised a phallus to wish for. Furthermore, the daughter, seeing herself as powerless in the symbolic order, has never been given an incentive to enter that order as a son. Allying with Homans, Kahn (1985: 75) notes that "Chodorow distinguishes two coexistent levels of gender identity [in the daughter]: one homosexually oriented towards the mother, one heterosexual toward that father." Not being completely accepted in the symbolic order, the daughter occupies a marginalized position on the borders of the Father's kingdom.

Chodorow's work sets a theoretical framework for the analysis of nineteenthcentury women writers, including Dickinson, who write from the position of daughter. Discussing the works of these women writers, Homans (1986: 16) says, " $19^{\text {th }}$ century writers articulate thematically a daughter's bond to and identification with a vulnerable or vanished mother (often figured as Mother Nature);...these writers are writing and practising myths of daughters' relations to symbolic language working out through their writing the conflict in being a daughter and being a writer." The myth of women writers searching for their lost mother country mentioned by Homans is well illustrated by Gilbert and Gubar's essay "The Parable of the Cave." In the "Parable" the mother is not simply seen as "vanished" and "vulnerable" but also as a source of power and creativity for her poetic daughters. One parable, included in Gilbert and Gubar's essay, is told by Mary Shelley. In this parable Shelley is led by her "male companion" to the cave of the Sibyl, ${ }^{7}$ where they find "piles of leaves, fragments of bark, and a white filmy substance" (Gilbert and Gubar 1989: 1121). Although the cave belongs to the mother goddess and female artist, the Sibyl, it is a man who not only finds the cave but is able to recognize it. "This is the Sibyl's cave; these are the sibylline leaves," claims Shelley's male companion (Gilbert and Gubar 1989: 1122). The

\footnotetext{
6 "The Parable of the Cave" is the third chapter of Gilbert and Gubar's book The Madwoman in the Attic (New Haven: Yale University Press, 1984).

${ }^{7}$ The Sibyl was a prophetess of the Ancient Greek and Roman Period. It has been estimated that there are as many as ten sibyls whose names appear in Greek and Latin texts. However, the most famous one is the Sibyl of Cumae who is assigned a crucial role in Virgil's Aeneid. It is also believed that she is the one who wrote nine books of prophecies. See Cavendish (1983: 2574-2575).
} 
parable reveals the "sad fact" about the "equivocal place" of women in patriarchal culture: they are at once a part of the culture and yet alien to the world controlled by men. However, all is not lost in Shelley's case since she is the one with the power to interpret the leaves of prophecies left by the Sibyl and convey them to a wider community. Gilbert and Gubar describe the nature of her mission:

But while the way to the cave can be "remembered" by accident, the whole meaning of the sibylline leaves can only be remembered through painstaking labor: translation, transcription, and stitchery, re-vision and recreation.

(Gilbert and Gubar 1989: 1122)

There are two ramifications to this statement. Firstly, the cave representing the mother's place is forgotten and has to be remembered. Secondly, this is not a discovery but a rediscovery of the power that was once wielded and that has been subjugated and suppressed by a maledominated society.

We must also consider the words Gilbert and Gubar use. This is a "labor" of "recreation" which connects this work to the act of giving birth. This is the maternal role, a role that can be filled only by women. For Gilbert and Gubar, Mary Shelley's act of translating the Sibyl's prophecies becomes one of birthing that connects the women writers to a sort of mother goddess. Gilbert and Gubar (1989: 1122) say, "She [the Sibyl] had, in other words, a goddess's power of the male potential for literary paternity." In recovering and reconstructing the Sibyl's "sexual/artistic strength," Shelley comes to realize the creative power she shares with the mother goddess. Shelley exclaims, while deciphering the sibylline leaves, that she feels herself "taken ... out of a world, which has averted its once benignant face from me, to one growing with imagination and power" (Gilbert and Gubar 1989: 1122).

Born in 1830, Dickinson was inevitably subject to the Victorian ideology of womanhood. As Joanne Dobson notes, "The cultural ideology of respectable womanhood in mid-nineteenth-century America was structured on the assumption of women's inmate and unique morality. It defined ideal feminine morality in a large part as altruism, selflessness and reticence" (Stein 1997: 26). A woman's life, especially that of a middle and upper class family, was thus confined to the domestic where she was expected to be the Angel in the house and a moral or spiritual guidance for men. As a daughter who also wrote, Dickinson found that the main question for her was not simply being female but being a female author. Writing her poems in a male-dominated literary world, Dickinson, as Stein (1997: 26) puts it, "[undertakes] a traditionally masculine role." Feminist literary critics have noted how literary tradition legitimates the male author and his authority. Citing Homans, Stein (1997: 27) says, "Western literary tradition, beginning with Genesis, assumes an Adamic male speaker and namer whose words have a portion of God's own verbal powers, whereby words create the things they name. [...] According to this view, poetry is a gendered enterprise; the speaker is male and his words reenact God's Logos that named the world into existence." The recovery of the lost maternal world was in order for Dickinson to find herself a place for her female selfaffirmation and her self-assertion as a female author. 


\section{II}

Dickinson's poetry, following the parable told by Shelley, illustrates the poet's search for the lost mother country. Although Chodorow emphasizes the prolonged relationship between mother and daughter, the inevitable fact is that the daughter does enter the symbolic order and experiences there a sense of the lost paradise of the mother's world and an alienation from the father's kingdom.

Dickinson's "As if some little Arctic flower" (\#180) portrays a little flower who wanders through the patriarchal Eden-a place describe as "continents of summer" and "firmaments of sun." The image of "summer" and "sun" are reminiscent of Dickinson's "man of noon." ${ }^{8}$ In her letter dated June 1852 to Susan Gilbert, ${ }^{9}$ Dickinson contemplates on the plight of womanhood:

How dull our lives must seem to the bride, and the plighted maiden, whose days are fed with gold, and who gather pearls every evening; but to the wife, Susie, sometimes the wife forgotten, our lives perhaps seem dearer than all others in the world; you have seen flowers at morning, satisfied with

\footnotetext{
${ }^{8}$ H. Jordan Landry (2004: 901) states,

"Throughout her poems and letters, Dickinson writes "noon" as the very sign under which women are subordinated and bodily threatened."

${ }^{9}$ Susan Gilbert was Dickinson's lifelong friend, neighbor and sister-in-law. Gilbert maintained a close relationship with Dickinson until she married Dickinson's brother, Austin, in 1986. Since Dickinson devoted a number of her poems to her dear friend "Sue," many critics have pointed out the erotic love between the two of them. See Hart (1990: 251-272).
}

the dew, and those same sweet flowers at noon with their heads bowed in anguish before the mighty sun; think you these thirsty blossoms will now need nought but—dew? No, they will cry for sunlight, and pine for the burning noon, tho' it scorches them, scathes them; they have got through with peace-they know that the man of noon, is mightier than the morning and their life is henceforth to him.

(Martin 1984: 149)

Dickinson contrasts the morning dew with the heating sun. The former suggests maternal nurturance which satisfies the child's needs while the latter represents the burning passion of male energy which promises nothing but death. Unlike those flowers in Dickinson's letter which "pine for the burning noon," the little flowers in the poem find themselves alienated from the patriarchal Eden where "bright crowds of flowers-/ And birds" speak a "foreign tongue."

In poem \#959, the speaker's sense of loss and alienation is accompanied by her yearning for an unnameable and unknowable something:
A loss of something ever felt I-
The first that I could recollect
Bereft I was - of what I know not
Too young that any should suspect

These lines suggest a child's traumatic experience of separation from her mother. The daughter feels the "loss of something" but cannot "recollect" any words to describe it since the loss here is the loss of the mother which occurs before the child enters the symbolic realm of language. The same experience is also mentioned by 
a male poet, Wordsworth, in the second book of The Prelude:

For now a trouble came into my mind

From unknown causes. I was left alone,

Seeking the visible world, not knowing why.

The props of my affections were remov'd,

And yet the building stood, as if sustain'd

By its own spirit!

(II, ii, 291-296)

Although the two poems describe the same $\operatorname{loss}{ }^{10}$, their emphasis is different. The male poet is looking forward to the "visible world" where he becomes an individual "sustained/ by [his] spirit." The speaker in Dickinson's poem, on the other hand, laments the loss of the mother's world which for her is the loss of her identity.

A Mourner walked among the children

I notwithstanding went about As one bemoaning a Dominion Itself the only Prince cast out-

Separated from the mother, the speaker in Dickinson's poem experiences absolute isolation; she is a "Prince cast out" from a "Dominion." In her critique of the development of the male and female subject, Annis Pratt argues that while society allows growth and individuality to the female subject, a woman who enters

\footnotetext{
${ }^{10}$ The lines convey the poet's sense of loss though not all critics agree that the trouble here is caused by the absence of the poet's mother (either literally or figuratively). See Havens (1936: 137-38)
}

the social enclosure "grows down" rather than "grows up" (1981: 18). Like a little flower threatened with being beaten down by the mighty sun, the speaker in this poem, "[a] Mourner walk[ing] among the children," is dwarfed by a society that both suppresses and dominates her.

In searching for the lost paradise, Dickinson questions the patriarchal myth of Eden. In "Did the Harebell loose her girdle" (\#213), dealing with the courtship of the lovers, Dickinson asks:

Did the "Paradise"-persuadeYield her moat of pearlWould the Eden be an Eden, Or the Earl—an Earl?

Dickinson deconstructs the authority of a transcendent God who represents the Word and His Paradise, which is suggested by the heterosexual relationship of the lovers. Dickinson's tentative use of the indefinite article "an" to replace the definite article "the" allows her to create another paradise (an Eden) and another God (an Earl). As illustrated by Lacan, the male's control of power is made possible by his control of language as part of the Father's law and order. In the poem, Dickinson obviously senses that language is a social construct, an instrument used by patriarchy to create its own myth. Dickinson therefore challenges the patriarchal order by challenging its language.

Dickinson's "Four Trees - upon a solitary Acre-" (\#742) challenges the Transcendental God and Western phallogocentrism. In the poem, God's great plan and order are substituted by the trees which occur "Without Desire/Or Order, or Apparent Action-/Maintain-." The breakdown of the apparent order does 
not bring about the chaos feared by male writers who see nature as the manifestation of a divine plan. As in Emerson's "The Apology," the poet enters "the god of the wood," where "There was never mystery/ But'tis figured in the flowers;/ Was never secret history/ but birds tell it in the bowers" (Stein 1997: 29). In Dickinson's poem, the absence of God's great plan and order is not something the poet laments. Rather, it signifies the poet's rejection of the Father's Law and her desire to become liberated from the confinement of domestic life. As the poet says of the trees in the final stanza, "What Deed is Theirs unto the General nature-/ What Plan-/ They severally-retard-or further--/ Unknown-." Unlike the male subjects who manage to recover the lost maternal world through their access to the Phallus, the symbol of masculine power, the poet's ambivalent position - her being a part of and yet excluded from the male-dominated world - causes her to feel alienated from the masculine world and culture. Her marginal position within the symbolic order makes it possible for Dickinson to expose the natural relationship between the word and the world, between God's "Plan" and material things as a man-made myth.

\section{III}

As a daughter who writes, Dickinson appropriates the Father's toollanguage - to reconstruct the lost Eden, a female version of utopia characterized by homosexual rather than heterosexual relationships. In The Reproduction of Mothering, Chodorow (1978: 169) argues that the child's ego boundaries are formed by its relationship with the mother. "From the retention of pre-oedipal attachments to the mother," explains Chodorow, "growing girls come to define themselves as continuous with others; their experience of self contains more flexible and permeable ego boundaries. Boys come to define themselves as more separate and distant, with a greater sense of ego boundaries and differentiation." Though she never clearly develops this aspect of her analysis, Chodorow implies here that, for women, lesbian relationships ${ }^{11}$ are bound to be more satisfying. Indeed Hirsch (1989: 134) also notes that Chodorow's theorization of these differences in male and female structures has "the effect of distancing not only woman from man in individual heterosexual relationships, but also, much more generally, feminine from masculine cultural realms; they create a myth of female separateness which underscores the value of empathy and connectedness, overturning traditional value structures and implying the superiority of women to men."

In poem \#24, Dickinson envisions this feminine world of culture:

There is a morn by men unseenWhose maids upon remoter green Keep their Seraphic MayAnd all day long, with dance and game,

And gambol I may never nameEmploy their holiday.

\footnotetext{
11 The term lesbian used here corresponds to what Adrienne Rich means when she talks about "lesbian continuum." According to Rich, "the term lesbian continuum [is meant] to include a range - through each woman's life and throughout history-of women-identified experience, not simply the fact that a woman has had or consciously desires genital sexual experience with another woman" (Rich 2003: 27).
} 
Dickinson's female utopia is that of the green world, the one women both connect and identify with. "For the young girl, for the woman who has not fully abdicated [to the symbolic realm]," says de Beauvoir (1953: 710-711), "nature represents what woman herself represents for man, herself and her negation, a kingdom and a place of exile; the whole in the guise of the Other." A woman's relationship with nature is described in terms of her relationship with the mother. Homans (1980: 32) also argues that "the child learns to love nature by gradually extending his love for his mother, and nature takes on a maternal configuration - the borders between nature and mother are permeable: the 'one beloved Presence' is the one manifestation of 'Presence Nature." In Dickinson's poem, the "mystic green" is a no-man's land where women "live aloud." They are engaged in "dance," "game" and "gambol" which the poet may "never name." This secret female enclave reminds us of the Greek Mysteries - the worship of mother goddesses such as Demeter and Isis. All female participants in these secret rituals are initiated into some esoteric knowledge about which they must close their lips. According to Rabuzzi (1988: 23), the goddess's power is closely associated with the cycle of life and death also found in nature: "one of [the goddess's] primary attributes is chthonicity, that is, earthrootedness. This attribute not only links her to the fertility of earth...but also with its opposite-death." Celebrating the power of the goddess she finds in nature, Dickinson exclaims with wonder: "Ne'er saw I such a wondrous scene-/ Ne'er such a ring on such a green."

In her discussion of Dickinson's nature poetry, Stein (1997: 26) argues that the poet expresses her "passion, intellect, and heterodox theoretical assertions" through her writing. Stein (1997: 37) notes the primacy of Mother Nature over God's Logos in a number of Dickinson's nature poems: "[N]ature's maternal presence, rather than God's paternal power, is represented as the constant, sustaining force of life." In the poem \#790, Dickinson personifies Nature as a nurturing mother

Nature-the Gentlest Mother is,
Impatient of no Child--
The feeblest_or the waywardest-
Her Admonition mild--
With infinite Affection
And infinite Care-
Her Golden finger on Her lip--
Wills Silence-Everywhere-

The personification of Nature as a mother figure is in sharp contrast with the cold and revenging nature of the Calvinist God. $^{12}$ In the poem, Dickinson denaturalizes the relationship between man and God. Stein (1997: 39) writes, "As a 'waywardest' believer, unwilling to accept much contemporary theological doctrine, Dickinson creates an alternative maternal deity who revises God-the Father's failings; this beneficent maternal image, projected throughout nature, embraces the wayward, transgressive behavior of the nonconforming woman poet who knows herself damned within

\footnotetext{
${ }^{12}$ The image of the Calvinist God as an angry and unpredictable God is vividly portrayed in Jonathan Edwards' "Sinners in the Hands of an Angry God." In this sermon, one finds "The God that holds you over the pit of hell, much as one holds a spider, or some loathsome insect, over the fire..." (See Gallagher 2000: 211).
} 
prevailing Christian doctrine, and this figure interrogates by ironic contrast our acceptance of a grim and absent male God.”

\section{IV}

The Eden reimagined in Dickinson's poetry is an exclusive place for women where they find a life nurturing force in same-sex relations. The Father's Law and Order are substituted by the female body and the mother's language of touch, taste and sound (humming). Through her use of bird and bee imagery, Dickinson redraws female desire from a heterosexual economy to a homosocial, even homoerotic, economy. Discussing how Dickinson "overlays the Puritan triangle with a zoological frame in order to lesbianize the process of conversion," Landry (2004: 901) similarly maintains:

Within Dickinson's poem, the Puritan metaphor of the marriage ceremony is replaced by the queer metaphor of the bee's ritual of pollination. In turn, the minister's persuasion of the convert to a belief in the phallicism of Christ is replaced by the masculine woman's guidance of the uninitiated woman to an awareness of the power of lesbian sexuality. And, finally, the memorializing of the Puritan convert's successful acceptance of Christ's phallic power through eating bread and drinking wine is exchanged for the celebration of the lesbian convert's embrace of the power of lesbian sexuality by drinking "Nectar." [...] As the female vagina replaces Christ's phallus though, conversion is not experienced by literally drinking wine and symbolically celebrating union with Christ's body but by literally "quaffing" the nectar of flowers and symbolically sipping woman's vaginal juices.

(Landry 2004: 901)

Dickinson's poem \#211 describes the emergence of the lost mother country - the land of milk and honey suggested by the poet's use of flower and bee imagery:
Come slowly- Eden!
Lips unused to thee-
Bashful- sip thy Jessamines-
As the fainting Bee-
Reaching late his flower,
Round her chamber hums-
Counts his nectars-
Enter-and is lost in Balms.

As de Beauvoir (1953: 711) says, "It is when she speaks of moors and gardens that [the woman] will reveal her experience and her dreams to us most intimately." In Dickinson's Eden, the garden of pleasure, the poet enjoys the heavenly bliss derived from her exercise of erotic imagination and her delight in the female body and sexuality as is implied by such words as "Lips," "Bashful," "sip," and "Jessamines." Bennett (1990: 165-66, emphasis added) in her book Emily Dickinson notes the homoerotic mode of Dickinson's sexual fantasy inherent in many of her poems including this one:

Profoundly attracted to the female body, Dickinson lets her love for it inform her erotic poetry even when she is, or seems to be writing heterosexual verse. Not only does she focus on female sexual power but her 'lover' who is invited to share this power, is 
rarely specified with a human male. Most often, he is a male bee and, hence, being small and round, ambiguously, a covert female symbol.

(Bennett 1990: 165-166)

Not only is the physical appearance of a bee associated with the female body but also a bee is historically linked with ancient mysteries organized by women. According to Hall (1980: 25), the bee is a symbol of immortality, the regenerative and destructive force attributed to both nature and the mother goddess. "In keeping with the bee metaphor," Hall (1980: 26) further says, "the initiate was called an incubant, from incubare or 'to dwell in a hive.' A set of instructions says that the first temple was, like a hive, constructed of bees' wax and birds' feathers: 'Brings feathers, ye birds, and wax, ye bees.' The temple attendants were priestesses called melissae, or 'bee maidens." The association of the bee with an esoteric group of female cultures gives a spiritual import to Dickinson's use of bee imagery. The poet, usually comparing herself to a flower (in her letters and poems), welcomes the bee, an agent of the mother goddess, who provides for her a spiritual renewal.

In poem \#334, Dickinson uses the bird and flower imagery to describe transgressive female sexuality:

All the letters I can write

Are not fair as this-

Syllables of Velvet-

Sentences of Plush,

Depths of Ruby, undrained,

Hid, Lip, for Thee-

Play it were a Humming Bird-

And just sipped-me-
Here the poet offers the letters to her reader (likely to be Susan Gilbert to whom many of Dickinson's poems and letters are addressed). But the letters/words are not phallocentric; they are "Syllables of Velvet" and "Sentences of Plush" that break boundaries, refusing to be confined to any order or category. Also, the confusion of the terms "write," "play" and "sipped" reveals that writing is indeed an erotic activity associated with female pleasure. The phallic word is substituted by the female body - the vagina or the "Ruby, undrained,/ Hid, Lip, for Thee-.,"13 Thus, in offering the letters to "Thee", the poet also conveys a hidden message - "the invitation to cunnilingus - $\mathrm{a}$ form of erotic activity to which, consciously or unconsciously, Dickinson appears to have been most drawn” (Bennette 1990: 167).

\section{V}

Reconstructing the lost mother country becomes important for the daughter's consciousness of her poetic identity. In Mary Shelley's version of the cave parable, the mother goddess, the Sibyl, is portrayed as a female artist whose poetic works, the sibylline leaves, are "shattered and scattered" by men. Gilbert and Gubar (1989: 1122) write, "Surrounded by the ruins of her own tradition, the leavings and unleavings of her spiritual mother's art, she [Mary Shelley] ...like someone suffering from amnesia. Not only did she fail to recognize - that is, to rememberthe cavern itself, she no longer knows its language, its message, its form." Chodorow's model of the symbiotic relationship between mother and daughter

\footnotetext{
${ }^{13}$ In This Sex Which Is Not One, Luce Irigaray also uses the vagina-lip as a metaphor for the female autoerotic desire. (See Irigaray 1985: 205-218).
} 
is thus applied by Gilbert and Gubar to female aesthetics. As the daughter models her femaleness on her mother, the female artist inherits a literary tradition from her poetic foremothers.

Dickinson's "To my quick ear the leavesconferred" (\#891) illustrates her version of the cave parable. Unable to find a Privacy/ from Nature's sentinels," the poet is exiled to an earthen cave:

In Cave if I presumed to hide The Walls - began to tellCreation seemed a mighty CrackTo make me visible-

The poet's resignation is far from being passive. Since "Creation seemed a mighty Crack" to make her "visible," the poet hides herself in a cave, allowing her "Privacy" to create her own craft. Kher (1974: 62) argues that Dickinson's withdrawal is part of her poetic strategy:

Absence as withdrawal embodies a special type of retreat from the world, a retreat in which the artist cultivates his or her own mode of encountering the world. This withdrawal is not a running away from reality but a process by which the artist ripens to a deeper perception of reality. Dickinson's own "deliberate and conscious" seclusion and aesthetic privacy should be interpreted as creative devices to meet the world on her own terms.

(Kher 1974: 62)

What is not mentioned in Kher's argument is the place of the poet's withdrawal. In the poem, Dickinson's return to a womblike cave is also a return to the mother goddess whose "sexual/ artistic strength," claim Gilbert and Gubar (1989: 1122 ), is "the female equivalent of the male potential for literary paternity." Although the cave may be a place of confinement, it is also a place where the work of art is conceived. As the cave combines both creation and recreation, the poet's return to the cave enables her to discover not only her lost selfhood but also her artistic identity.

According to Northrop Frye (Gilbert and Gubar 1989: 1123), a revolutionary "mother-goddess myth," which allows power and dignity to women, "is antihierarchal,... [and] liberate[s] the energy of all living creatures." Frye's statement is reinforced by Rich's Utopian vision at the end of her article "When We Dead Awaken":

A new generation of women poets is already working out of the psychic energy released when women begin to move out towards what the feminist philosopher Mary Daly has described as the "new space" on the boundaries of patriarchy. Women are speaking to and of women in these poems, out of a newly released courage to name, to love each other, to share risk and grief and celebration.

(Rich 1979: 49)

Dickinson's poetry prefigures Rich's utopian vision. What is seen to be retrieved here is the matriarchal myth, namely, the myth of the Sibyl, the woman artist and prophetess, that has been suppressed by patriarchal society.

In Dickinson's poem \#1677, the womblike cave of the earlier poem is replaced by a volcano. While in the earlier poem the female artist escapes from the outside 
world into the cave, in this poem she becomes the cave itself - a volcano, and inherits from her mother goddess her "sexual/ artistic" energy:

On my volcano grows the Grass A meditative spot-

An acre for a Bird to choose

Would be the General thought-

How red the Fire rocks belowHow insecure the sod

Did I disclose

Would populate with awe my solitude.

In her article, "Vesuvius at Home," Rich's discussion of Dickinson's "creative and powerful" self hidden within a publicly acceptable persona focuses on the poet's use of imagery including the volcano. Describing Dickinson, Rich (1979: 169) says, "The woman who feels herself to be Vesuvius at home has need of a mask, at least, of innocuousness and of containment." In the poem, Dickinson paradoxically finds her artistic freedom within limited boundaries. Just as the cave is a place of confinement and artistic creativity, the volcano is simply "A meditative spot" but contains "the General thought." Conscious of the violent and explosive power of the mother goddess she is assuming, Dickinson keeps it secret from the male culture.

In short, reimagining Eden - the lost mother's country-becomes an important task for a daughter who enters the symbolic realm of the Father. While a woman suffers from the psychic loss of the mother's world which has never been compensated in the symbolic order, the son who enters the same order comes to identify with the Father and inherits his law and power. As many feminist critics have pointed out, the daughter's marginalized position in the symbolic order-her being alienated from patriarchal culture and her prolonged relationship with the mother-enables her to play the subversive role of deconstructing the Father's law and remembering the lost mother continent. As a daughter who also writes, Dickinson describes this lost Eden as a green world of nature which is equated to the lost mother's body. However Dickinson occupies a reserved position since this resurrected continent, though conceived by the poet, remains separate and hidden from the masculine world of culture. An attempt to bring this female world and its lost tradition into a relationship with the Father's kingdom and its culture is the challenging task awaiting the poets of the next generation to undertake.

\section{References}

Bennett, Paula. 1990. Emily Dickinson: Woman Poet. New York: Harvester.

Cavendish, Richard. 1983. Man, Myth and Magic. New York: Marshall Cavendish Ltd.

Chodorow, Nancy. 1978. The Reproductions of Mothering: Psychoanalysis and the Sociology of Gender. Berkeley: University of California Press.

De Beauvoir, Simone. 1953. The Second Sex.. New York: Knopf.

Dickinson, Emily. 1960. The Complete Poems of Emily Dickinson, edited by Thomas H. Johnson. Boston: Little, Brown. 
Gallagher, Edward J. 2000. "Sinners in the Hands of an Angry God": Some Unfinished Business. The New England Quarterly 73.2: 202-221.

Gilbert, Sandra and Susan Gubar. 1984. The Madwoman in the Attic. New Haven: Yale University Press.

---. 1989. The Parables of the Cave. In The Critical Tradition: Classical Texts and Contemporary Trends, edited by David H. Ritcher. New York: Bedford.

Hall, Nor. 1980. The Moon and the Virgin: Reflections on the Archetype Feminine. New York: Harper \& Row.

Hart, Ellen Louise. 1990. The Encoding of Homoerotic Desire: Emily Dickinson's Letters and Poems to Susan Dickinson 1950-1886. Tulsa Studies in Women's Literature 9.2: 251-272.

Havens, Raymond D. 1936. Wordsworth's Adolescence. Modern Language Notes 51.3: 137-142.

Hirsch, Marianne. 1989. The Mother/Daughter Plot: Narrative, Psychoanalysis, Feminism. Bloomington: Indiana University Press.

Homans, Margaret. 1980. Women Writers and Poetic Identity: Dorothy Wordsworth, and Emily Dickinson. New Jersey: Princeton University Press.

---. 1986. Bearing the Word: Language and Female Experience in NineteenthCentury Women's Writing. Chicago: Chicago University Press.

Irigaray, Luce. 1985. This Sex Which Is Not One. Ithaca, New York: Cornell University Press.
Kahn, Coppelia. 1985. The Hand that Rocks the Cradle: Recent Gender Theories and Their Implications. In The (M)other Tongue: Essays in Feminists Psychoanalytic Interpretation, edited by Shirley Nelson Garner, et. al. Ithaca: Cornell University Press.

Kher, Inder. 1974. The Landscape of Absence: Emily Dickinson's Poetry. New Haven: Yale University Press.

Lacan, Jacques. 1977. Ecrits: A Selection. New York: Norton.

Landry, H. Jordan. 2004. The Touched, The Tasted, and The Tempted: Lesbianizing Triangles of Puritan Conversion Narratives in Emily Dickinson. Women's Studies 33: 875906.

Lorraine, Tamsin E. 1990. Gender, Identity, and the Production of Meaning. Boulder: Westview Press.

Martin, Wendy. 1984. An American Triptych: Anne Bradstreet, Emily Dickinson, Adrienne Rich. Chapel Hill: University of North Carolina Press.

Pratt, Annis. 1981. Archetypal Patterns in Women's Fiction. Bloomington: Indiana University Press.

Rabuzzi, Kathryn Allen. 1988. Motherself: A Mythic Analysis of Motherhood. Bloomington: Indiana University Press.

Rich, Adrienne. 1979. Vesuvius at Home: The Power of Emily Dickinson. On Lies, Secrets, and Silence. New York: W.W. Norton.

---. 1979. When We Dead Awaken: Writing as Re-Vision. On Lies, 
Secrets, and Silence. New York: W.W.

Norton.

---. 2003. Compulsory Heterosexuality and Lesbian Existence (1980). Journal of Women's History 15.3: 11-48.

Silverman, Kaja. 1983. The Subject of Semiotics. New York: Oxford University Press.

Stein, Rachel. 1997. Shifting the Ground: American Women Writer's Revision of Nature, Gender, and Race. Charlottes Ville and London: University Press of Virginia.

Wordsworth, William. 1933. The Prelude (1805). In The Prelude: or, Growth of a Poet's Mind (Text of 1805), edited by Ernest de Selincourt. London: Oxford University Press.

Wright, Elizabeth. 1984. Psychoanalytic Criticism: Theory in Practice. London: Methuen. 